Article

\title{
Economic Contribution Analysis of National Estuarine Research Reserves
}

\author{
Owen Stokes-Cawley ${ }^{1}$, Hannah Stroud ${ }^{1}$, Douglas Lyons ${ }^{1}$, Peter Wiley ${ }^{2}$ and Charles Goodhue ${ }^{1, *}$ \\ 1 Eastern Research Group, Inc., 110 Hartwell Ave, Lexington, MA 02421, USA; \\ owen.stokes-cawley@erg.com (O.S.-C.); Hannah.Stroud@erg.com (H.S.); Douglas.Lyons@erg.com (D.L.) \\ 2 NOAA Office for Coastal Management, 2234 South Hobson Ave, Charleston, SC 29405, USA; \\ Peter.Wiley@noaa.gov \\ * Correspondence: Charles.Goodhue@erg.com
}

Citation: Stokes-Cawley, O.; Stroud, H.; Lyons, D.; Wiley, P.; Goodhue, C. Economic Contribution Analysis of National Estuarine Research Reserves. Water 2021, 13, 1596. https:// doi.org/10.3390/w13111596

Academic Editors: Robert C. Burns and Danielle Schwarzmann

Received: 31 March 2021

Accepted: 2 June 2021

Published: 5 June 2021

Publisher's Note: MDPI stays neutral with regard to jurisdictional claims in published maps and institutional affiliations.

Copyright: (c) 2021 by the authors. Licensee MDPI, Basel, Switzerland. This article is an open access article distributed under the terms and conditions of the Creative Commons Attribution (CC BY) license (https:// creativecommons.org/licenses/by/ $4.0 /)$.

\begin{abstract}
Increased attention to the value of protected natural areas has led to the proliferation of ecosystem service valuations for coastal habitats. However, these studies do not provide a full representation of the economic value of these habitats. Protected coastal environments, such as the National Estuarine Research Reserve System (NERRS), add jobs and revenue to their local communities. Institutions such as NERRS provide economic contributions that extend beyond their operational spending and jobs they provide. Spending by reserves and their partners ripples throughout the economy. We performed an economic contribution analysis at four pilot sites using input-output modeling through IMPLAN. Sites contributed millions in revenue and tens to hundreds of jobs in their respective regions. Each of the four sites had a different category of spending that was the largest contributor of revenue and jobs, which is likely due to the community context and location of the reserves. Understanding these contributions is helpful in validating funding for NERRS. Communicating these contributions along with ecosystem service values may increase support from community members who otherwise do not use or rely on NERRS as much as traditional reserve supporters.
\end{abstract}

Keywords: economic contribution analysis; research reserves; input-output modeling; economic communications

\section{Introduction}

The National Estuarine Research Reserve System (NERRS) covers over 1.3 million acres of estuaries across twenty-nine sites throughout the United States and represents a partnership between the National Oceanic and Atmospheric Administration (NOAA) and coastal states. These estuarine systems support crucial coastal habitats that provide key ecosystem services from supporting fisheries, improving water quality, and protecting coastlines from storm surge [1]. The reserves provide educational and recreational opportunities, support restoration projects, and contribute useful research and costal management. In fiscal year 2019, NOAA spent over USD 27 million investing in the NERRS [2]. That investment was matched by over USD 9.5 million from state and university partners [2]. For such a substantial investment, their contributions to job creation and local revenue are understudied.

Many studies have sought to quantify economic benefits from natural and protected spaces such as the NERRS [3-5]. A survey in 2016 quantified the total economic value of the National Park Service, evaluating the existence and use values of national parks and programs [6]. Valuing ecosystem services of coastal areas is a popular practice among academics and institutions seeking support for funding [7]. However, these types of studies often focus on cultural ecosystem services, such as recreation, and assign nonmarket values, such as willingness to pay for the use of a resource $[4,8]$. The emphasis on cultural ecosystem services for marine areas tends to value benefits of direct users of these 
spaces instead of the community at large. There is little evidence that ecosystem service valuations are used in the decision-making process [4]. However, economic contribution analyses have been shown to influence decision makers' attitudes [9]. Despite this, the economic contributions to local jobs and revenue of reserve sites are less well understood.

Reserves contribute to the regional economy through attracting visitors, who spend money locally during their visit, spending on operations, and collaborating with partners who spend money on their operations and attract additional visitors to the area [10]. The reserve, its visitors, and its partners spend locally, which results in direct, indirect, and induced impacts, creating a multiplier effect. This effect is quantified in an economic contribution analysis. There are several different input-output models available for estimating economic contributions. This study used IMPLAN, a modeling software originally developed for the US Department of Agriculture to estimate economic impacts of forest related industries [8]. Several studies have utilized IMPLAN to assess the economic contributions of recreation and tourism of natural or semi natural spaces [11-17]. Many of these studies focus on visitor spending, often ignoring the impact of operational spending of parks departments or other stewards of natural spaces. Even some studies that analyze the impact of specific sites (rather than the recreation or ecotourism industry) only consider tourist spending $[13,15]$. This study investigated the feasibility of performing an economic contribution analysis for sites within the NERRS by providing a methodology using input-output models to value the economic contributions of four sites.

We define economic contributions as the value of existing economic activity in a region (employment, revenue, value added, and labor income), while economic impacts represent economic activities that would not have otherwise occurred in the region if the reserves did not exist [18]. This study sought to better understand, identify, and estimate the economic contribution of reserves. This paper concludes with a short discussion of how the results of such studies could be used by reserves. In developing the methodology, we began the study by identifying existing data for all reserves and identifying data gaps that may undermine an economic contribution analysis.

\section{Materials and Methods}

We created a replicable method for performing economic contribution analyses of the reserves using each reserve's spending in the area, visitor spending, and visitation and employment of the reserve's partners. We report the results of our economic contribution analysis in terms of revenue, employment, labor income, and value added. We defined employment as the number of full-time jobs. Revenue is the total amount of money spent on the productions of goods and services and is often referred to as "output". Value added is the dollar value that a sector adds to the economy by buying up labor and resources and producing final goods and services. Labor income is the wages paid as a result of economic activity.

We examined four reserves in 2019 and 2020 through on-site or virtual meetings. In 2019, we conducted this study for the Guana Tolomato Matanzas (GTM) Reserve and Rookery Bay Reserve, both in Florida. We followed up with the South Slough Reserve in Oregon and the Apalachicola Reserve in Florida. While we reached out to reserves across the system to include sites from a variety of locations across the country in this study, site locations were constrained by the availability and willingness of reserve managers to participate and availability of their spending data. While there is a geographic bias in sites, the reserves selected still cover a diversity of settings within the reserve system. Apalachicola and South Slough are located further away from large population centers compared to Rookery Bay and GTM. The reserves range in size, number and type of partners, and number of visitors.

First, we created a study region which was chosen in conjunction with the reserves. Literature is lacking that prescribes how to create a study region. By making the study region larger, the overall outputs will increase; however, these outputs will be diluted by spreading the outputs (i.e., wages, jobs, revenue) over a much larger region. Thus, we 
worked with the reserves to select regions where there was a strong economic tie to the reserve. Two major drivers for this were from where employees were commuting, as they would be spending their salary in that community, as well as where major suppliers of the reserve were located. The study areas typically resulted in being represented by the counties the reserves were located in and possibly some or all of the adjacent counties.

Second, we assessed local spending by each reserve. The reserves spend money in the local economy to conduct research, provide educational programs, and run day-to-day operations. We worked with reserves to establish the portion of their budget that was spent in the selected region and used IMPLAN to see how these funds impact other sectors in the economy. If a reserve spends USD 10,000 annually for auto repair to carry out operations, but only spends $50 \%$ of that within the study region, we allocated USD 5000 to IMPLAN sector 512 (automotive repair and maintenance, except car washes, as of 7 May 2021). We used sector output for each budget allocation except salary, which we allocated as industry compensation. We repeated this for each element of the annual budget, using $25 \%$ increments as the estimates for how much was spent within the study region. We used $25 \%$ increments because we felt this was granular enough to draw conclusions, while requiring more specific data would have significantly increased the level of effort.

Third, we selected expenditure studies and collected available visitation data to quantify reserve visitors' economic contribution to the economy. Our goal was to multiply the average visitor expenditure by the number of annual visitors $[11,16,19,20]$. To capture annual estimates of their visitors, we gathered a list of common activities at the reserves and went through this list with reserve staff. Many reserves already count the number of visitors for certain activities, such as attending educations programs and visiting the visitors center. For other activities, such as hiking and boating, visitor numbers are difficult to estimate, and reserves have not been able to accurately measure them due to the vast areas of land or water as well as numerous access points. To make our estimates conservative and not overestimate the reserve's contribution, we asked the reserves to estimate the absolute minimum visitation as opposed to making an educated guess. For example, the Apalachicola Reserve estimated that there are around 100,000 boaters that visit the reserve every year, but they are much more confident that at least 50,000 boaters visit annually, so we used 50,000 boaters in our estimate to limit the chance of overestimating.

To estimate visitor spending, we performed a literature review of available expenditure surveys since conducting an expenditure review at the reserves was outside the scope of this project. We focused on areas conserved under the NOAA umbrella, such as National Marine Sanctuaries, with a priority for areas that had similar visitation activities to the reserves. Ultimately, this led us to focus on a 2015 study on National Marine Sanctuaries [10]. This study surveyed individuals at three National Marine Sanctuaries on the West Coast. We applied the data from the northern portion of Monterey Bay because it had a visitor activity profile similar to the GTM and Rookery Bay Reserves. For the Apalachicola and South Slough Reserves, we chose to use expenditure studies that were specific to their respective states, Florida and Oregon. We chose the 2011 National Survey of Fishing, Hunting, and Wildlife-Associated Recreation (NSFHWAR) [21,22]. This survey was performed in all fifty states, so we applied the visitor spending data from Florida and Oregon to this analysis. Fourth, we considered two different types of partners for this study to identify additional contributions: collaborative partners, such as state agencies operations or programs that exist, in part, based on the presence of the reserve; or private partners, businesses that operated within the reserve boundaries, such as ecotourism companies that rely on the reserve or exist because of the reserve. For private companies that operate independently within reserve boundaries, we attempted to acquire employee and visitation data. For collaborative partners, we attempted to gather the amount of collaboration as well as visitation and employment data. We worked with the reserves to gather a list of partners and gather the relevant data.

We used IMPLAN for our economic contribution analyses. IMPLAN is an inputoutput modeling software. This model uses expenditures in the study region to calculate 
resulting contributions using multipliers. Multipliers are a set of numbers that represent how money spent in one sector within the regional economy contributes to another sector. On a broad level, input-output models estimate how money flows through a regional economy. We chose IMPLAN over other input-output software because it provides flexibility in selecting the geographic region, outputs by sector, and costs within the budget available for this project. IMPLAN's flexibility to combine geographic regions was particularly important to this project, as several study regions contained multiple counties, and we were exploring possibilities about which counties to include in our study region. Other models would have restricted how we could have explored the selection of our geographic study area. IMPLAN also has a large collection of sectors built into its base model, which can generate sector-level outputs, which was important to understand in communicating the outputs to stakeholders. The Bureau of Economic Analysis' RIMS II multipliers, for example, only provide aggregate output (across all sectors) for each given study area.

Fifth, we input spending from reserve operations, visitors, and partners into the corresponding IMPLAN sectors. When more than one IMPLAN sector applied to a single category of the expenditures, we split them evenly across sectors. Expenditure studies were input into IMPLAN as a group and the group was multiplied by the number of visitors. For the South Slough and Apalachicola Reserves, we used different expenditures that varied by activity (fishing, hunting, or wildlife viewing). When the activity was not specifically mentioned (i.e., hunting or fishing), we allocated it to wildlife viewing. We did this because hunting and fishing require specific equipment that could result in more spending while other categories, such as hiking, attending an education session, or kayaking, are less likely to require equipment that overlap with hunting and fishing. IMPLAN calculated the direct, indirect, and induced contributions. We also captured the individual contributions from reserve spending, reserve visitors, partner employment, and partner visitation. Contributions were broken down by labor income, value added, employment, and output.

\section{Results}

For each reserve, we input their spending, visitor expenditure profiles-which we borrowed from similar studies due to lack of NERR-based data-visitation data, partner spending, and partner visitor data into IMPLAN. We worked with each reserve to allocate their annual spending into IMPLAN sectors that capture the local spending. Visitor data were broken down by activity. IMPLAN then applied a series of sector-based multipliers to each expenditure category to estimate the total annual economic contributions. The average reserve budget for the fiscal year 2019 was USD 1.25 million [2]. Individual budgets are not subject to public review. Across the reserves, the percent spent locally and the types of expenditures varied.

\subsection{Guana Tolomato Matanzas}

\subsubsection{Reserve Study Area}

We established a study area that consisted of Flagler County, Duval County, and St. Johns County in northeast Florida. This area is where most of reserve spending occurs and most of the reserve employees live.

\subsubsection{Visitors}

During our meeting with GTM, they estimated the number of visitors to the reserve. We worked with the reserve to break down visitation by activity (i.e., hiking, fishing, attending educational events, etc.). The reserve had data for some activities, but had to estimate some, as well. For estimates, we asked the reserve to be conservative, opting for the smallest possible number of visitors instead of attempting to estimate an accurate number and potentially overestimating economic contributions. We also included the visitors to reserve partners. The GTM Reserve works with several partners that include 
state parks, state forests, other conserved lands, and private ecotourism companies. Table 1 shows the number of visitors by activity, including the visitors to reserve partners.

Table 1. Estimated number of annual visitors to the GTM Reserve by activity type.

\begin{tabular}{cc}
\hline Activity & Visitors \\
\hline Beachgoing & 128,795 \\
Hiking, wildlife viewing, kayaking, fishing, and horseback riding & 84,166 \\
Citizen science events and educational events & 7000 \\
Attending other reserve events & 1000 \\
Hunting & 1000 \\
Research & 400 \\
Reserve partners & 760,611 \\
Total & 982,972 \\
\hline
\end{tabular}

\subsubsection{Expenditures}

We applied the visitor expenditures to the northern portion of the Monterey Bay National Marine Sanctuary as our expenditure study to the GTM Reserve [10]. This survey included visitors to the National Marine Sanctuary and included activities similar to activities available at the GTM Reserve. Table 2 shows the expenditure study categories applied to IMPLAN sectors and adjusted to 2020 USD using the GDP deflator method [21]. IMPLAN sectors are as of the fall of 2019.

Table 2. Per-person-per-day visitor expenditures by category.

\begin{tabular}{|c|c|c|c|}
\hline Expenditure Category & Value (USD) & Adjusted Value (USD) & IMPLAN Sector $^{1}$ \\
\hline Food and beverages at a restaurant or bar & 8.56 & 9.87 & $501 / 502$ \\
\hline Lodging & 5.52 & 6.36 & 499 \\
\hline Food and beverages from a store & 3.46 & 3.99 & 400 \\
\hline Souvenirs (t-shirts, posters, gifts, etc.) & 1.64 & 1.89 & 405 \\
\hline Parking & 0.94 & 1.08 & 526 \\
\hline Museum, aquarium, or other entrance fee & 1.45 & 1.67 & 526 \\
\hline Car rental & 0.33 & 0.38 & 442 \\
\hline Sundries (sunscreen, surf wax, motion sickness) & 0.74 & 0.85 & 404 \\
\hline Boat rental & 0.37 & 0.43 & 443 \\
\hline Charter fee & 0.74 & 0.85 & 414 \\
\hline Bike rental & 0.36 & 0.41 & 443 \\
\hline Lessons, clinics, camps & 0.70 & 0.81 & 526 \\
\hline Kayak rental & 0.66 & 0.76 & 443 \\
\hline Boat fuel & 0.44 & 0.51 & 402 \\
\hline Surfboard or body board rental & 0.64 & 0.74 & 443 \\
\hline Ramp fees & 0.02 & 0.02 & 526 \\
\hline Total & & 30.62 & \\
\hline
\end{tabular}

${ }^{1}$ IMPLAN sectors as of June 2020.

\subsubsection{Contributions}

Table 3 presents the estimated annual economic contributions due to reserve, reserve visitors, partners, and partner visitor spending to Flagler, Duval, and St. Johns counties. The majority of GTM contributions came through partners' visitor spending. GTM is located in a high population area and attracts many tourists to its beaches and other recreational areas that attract a large number of visitors.

Appendix A provides a breakdown of contributions by direct, indirect, and induced contributions from reserve operations, visitors, and reserve partners, along with the top five affected sectors by employment and revenue. 
Table 3. Estimated annual contributions to employment, labor income, value added, and revenue of GTM to Duval, Flagler, and St. Johns counties by spender.

\begin{tabular}{ccccc}
\hline Spender & Employment & Labor Income (USD) & Value Added (USD) & Revenue (USD) \\
\hline Reserve & 48 & $1,884,000$ & $3,201,000$ & $5,553,000$ \\
Visitors & 90 & $3,439,000$ & $5,829,000$ & $9,914,000$ \\
Reserve partners & 75 & $3,040,000$ & $4,373,000$ & $8,249,000$ \\
Partner visitors & 308 & $11,763,000$ & $19,940,000$ & $33,912,000$ \\
Total & 521 & $20,125,000$ & $33,343,000$ & $57,627,000$ \\
\hline
\end{tabular}

\subsection{Rookery Bay}

\subsubsection{Reserve Study Area}

We chose Lee County and Collier County as the Rookery Bay study area. Though the reserve is located in Collier County, Lee County to the north has a greater population and is only a short distance from the reserve, and therefore is where most of the spending occurs outside of Collier County.

\subsubsection{Visitors}

The same procedures used with GTM were followed for Rookery Bay to estimate annual visitors by activity. The reserve had data for some activities, such as boating, where they observed boat ramps, but had to estimate some as well, for which they gave conservative estimates. The Rookery Bay Reserve works with several private ecotourism companies as well as state-owned lands. Table 4 shows the number of visitors by activity, including visitors to reserve partners.

Table 4. Estimated annual visitors to the Rookery Bay Reserve by activity type.

\begin{tabular}{cc}
\hline Activity & Visitors \\
\hline Hiking and wildlife viewing & 20,000 \\
Camping & 500 \\
Canoeing/kayaking & 750 \\
Attending education events & 2700 \\
Boating & 261,119 \\
Other reserve events & 300 \\
Reserve partners & 381,825 \\
Total & 667,194 \\
\hline
\end{tabular}

\subsubsection{Expenditures}

Similar to our analysis for the GTM Reserve, we applied the expenditure survey from the northern portion of the Monterey Bay National Marine Sanctuary as an expenditure study to Rookery Bay visitors [10]. Table 2 shows the expenditure study categories applied to IMPLAN sectors and adjusted to 2020 USD using the GDP deflator method [21].

\subsubsection{Contributions}

Table 5 contains the IMPLAN results of the estimated jobs, labor income, value added, and revenue contributed by the reserve, its visitors, its partners, and partner visitors. Rookery Bay's largest economic contribution came from partner employment. Similar to GTM, Rookery Bay is in a high population area that attracts many tourists. Its multiple partners rely on the reserve's existence to protect and restore habitat for them to operate. A further breakdown of direct, indirect, and induced contributions is provided in Appendix A, along with the top five affected sectors by employment and by revenue. 
Table 5. Estimated annual contributions to employment, labor income, value added, and revenue by Rookery Bay Reserve.

\begin{tabular}{ccccc}
\hline Spender & Employment & Labor Income (USD) & Value Added (USD) & Revenue (USD) \\
\hline Reserve & 29 & $1,295,000$ & $2,373,000$ & $4,463,000$ \\
Visitors & 105 & $4,134,000$ & $6,970,000$ & $11,755,000$ \\
Partners & 239 & $8,088,000$ & $11,755,000$ & $23,629,000$ \\
Partner visitors & 140 & $5,531,000$ & $9,327,000$ & $15,421,000$ \\
Total & 512 & $19,047,000$ & $30,425,000$ & $55,038,000$ \\
\hline
\end{tabular}

\subsection{South Slough}

\subsubsection{Reserve Study Area}

The study area for South Slough consisted of Coos County. Coos County is very large and it is where most of the reserve employees live and the majority of local spending takes place.

\subsubsection{Visitors}

Following the same procedures used with GTM and Rookery Bay, we worked with South Slough to estimate and break down their visitation by activity (i.e., hiking, fishing, visitor center, etc.). The reserve had data for some activities but had to estimate some as well. For estimates, we cautioned the reserve to be conservative. Table 6 shows the number of visitors by activity.

Table 6. Annual visitors to the South Slough Reserve by activity type.

\begin{tabular}{cc}
\hline Activity & Annual Visitors \\
\hline Visitor center & 4691 \\
Attending education events & 2280 \\
Other visitors & 784 \\
Visiting researchers & 184 \\
Other reserve events & 2008 \\
Total & 9947 \\
\hline
\end{tabular}

\subsubsection{Expenditures}

We applied the NSFHWAR for Oregon as an expenditure study [22]. This study surveyed both residents and non-residents participating in fishing, hunting, or wildlife viewing, and captured their annual spending per trip as well as the average amount of trips per person. We calculated the per-person-per-day expenditures from these data and applied them into IMPLAN sectors which are shown in Table 7 . We adjusted the values to 2020 USD using the GDP deflator method [21].

Table 7. Per-person-per-day visitor expenditures in Oregon by category with corresponding IMPLAN sector.

\begin{tabular}{ccc}
\hline Category & Wildlife Viewing & IMPLAN Sector ${ }^{\mathbf{1}}$ \\
\hline Food & 12.17 & $509 / 510 / 511$ \\
Lodging & 16.08 & $507 / 508$ \\
Transportation & 14.26 & $418 / 420 / 408$ \\
Equipment & 38.93 & 504 \\
Other costs & 1.05 & $404 / 405 / 410$ \\
Total & 82.49 & \\
\hline
\end{tabular}

${ }^{1}$ IMPLAN Sectors as of June 2020.

\subsubsection{Contributions}

Table 8 presents the IMPLAN results estimating the contributions of reserve and visitor spending. 
Table 8. Estimated annual contributions to employment, labor income, value added, and revenue by South Slough Reserve.

\begin{tabular}{ccccc}
\hline Spender & Employment & Labor Income (USD) & Value Added (USD) & Revenue (USD) \\
\hline Reserve & 56 & $1,951,000$ & $2,626,000$ & $5,305,000$ \\
Visitors & 10 & 340,000 & 480,000 & 847,000 \\
Total & 66 & $2,290,000$ & $3,106,000$ & $6,153,000$ \\
\hline
\end{tabular}

South Slough is much smaller compared to Rookery Bay and GTM. Additionally, it is located in a more remote area, which does not have as large of a tourism base. South Slough did not have any partners that they determined relied heavily on the reserve, or the conserved land, to operate. The majority of its contributions are from operational spending. Appendix A contains a breakdown of contributions by direct, indirect, and induced contributions and the top five most affected sectors by employment and revenue.

\subsection{Apalachicola}

\subsubsection{Reserve Study Area}

The Apalachicola study area consisted of Franklin County. The majority of employees live in this county and the majority of spending takes places in the area, as well. Even though the reserve stretches into Gulf and Liberty Counties, the reserve does not interact enough with the local economies to include them in this study.

\subsubsection{Visitors}

As with the other reserves, we used the same procedures with Apalachicola to break down visitation by activity. The reserve had data for some activities but had to estimate some, as well. For estimates, we opted for the smallest number that they know are visiting. For example, in order to estimate camping in the reserve, we found the overall recreational vehicle (RV) capacity (104 slips) within the reserve and multiplied that by the lower end of the average annual occupancy $(60-75 \%)$. This captures a conservative estimate of the number of groups that camp in the reserve annually, assuming one family or group per $R V$. We combined this estimate with the per-spender-per-day expenditures instead of the per-person-per-day to get the contributions. Table 9 shows the number of visitors by activity. We also included the visitors to reserve partners in Table 9.

Table 9. Annual visitors to the Apalachicola Reserve by activity type.

\begin{tabular}{cc}
\hline Activity & Annual Visitors \\
\hline Visitor center & 25,000 \\
Hiking and wildlife viewing & 50,000 \\
Canoeing/kayaking & 25,000 \\
Camping & 22,776 \\
Beachgoing & 300,000 \\
Boating and fishing & 50,000 \\
Hunting & 1000 \\
Attending education events & 1000 \\
Visiting researchers & 24 \\
Other reserve events & 1277 \\
Reserve partners & 16,000 \\
Total & 492,077 \\
\hline
\end{tabular}

\subsubsection{Expenditures}

We applied the 2011 NSFHWAR for the state of Florida as our expenditure study for the Apalachicola Reserve [22]. We calculated the per-person-per-day spending for each category listed in Table 10 for hunting, wildlife viewing, and fishing. As noted in Section 3.4.2, we captured the number of groups of campers instead of individuals camping. Since the NSFHWAR includes spending by-participant as well as by-spender (e.g., a family camping could be made of four participants but only one spender), we were able to apply 
the by-spender expenditures to the number of groups camping, instead of applying the perparticipant spending to the number of individuals. Table 10 shows the expenditure study split into IMPLAN sectors and adjusted to 2020 USD using the GDP deflator method [21].

Table 10. Per-person-per-day visitor expenditures in Florida by category per activity type with corresponding IMPLAN sector.

\begin{tabular}{cccccc}
\hline Category & $\begin{array}{c}\text { Wildlife Viewing } \\
\text { (USD) }\end{array}$ & Fishing (USD) & Hunting (USD) & Camping (USD) & IMPLAN Sector ${ }^{1}$ \\
\hline Food & 15.42 & 12.80 & 16.45 & 13.36 & $509 / 510 / 511$ \\
Lodging & 16.09 & 4.85 & 0.00 & 37.14 & $507 / 508$ \\
Transportation & 20.34 & 11.04 & 26.77 & 16.72 & $418 / 420 / 408$ \\
Equipment & 10.71 & 20.26 & 42.28 & 14.76 & 504 \\
Other costs & 7.88 & 26.27 & 17.13 & 8.69 & $404 / 405 / 410$ \\
Total & 70.43 & 75.22 & 102.63 & 90.67 & \\
\hline
\end{tabular}

${ }^{1}$ IMPLAN sectors as of June 2020.

\subsubsection{Contributions}

Table 11 contains the estimated annual contributions from IMPLAN of the reserve, visitors, its partners, and partner visitors to Franklin County. The reserve's largest contribution comes from visitor spending. Like South Slough, Apalachicola is located further away from high population centers such as GTM and Rookery Bay. While it attracts a large number of visitors, it determined to only have one partner that relied heavily on the reserve.

Table 11. Estimated annual contributions to employment, labor income, value added, and revenue by Apalachicola Reserve.

\begin{tabular}{ccccc}
\hline Spender & Employment & Labor Income (USD) & Value Added (USD) & Revenue (USD) \\
\hline Reserve & 28 & 943,000 & $1,414,000$ & $2,922,000$ \\
Visitors & 615 & $13,668,000$ & $21,199,000$ & $41,971,000$ \\
Partners & 1 & 45,000 & 66,000 & 133,000 \\
Partner visitors & 20 & 446,000 & 696,000 & $1,383,000$ \\
Total & 664 & $15,103,000$ & $23,374,000$ & $46,408,000$ \\
\hline
\end{tabular}

Appendix A provides a detailed breakdown of Apalachicola's direct, indirect, and induced contributions, and its top affected sectors by employment and revenue.

\subsection{Limitations}

This study was limited by lack of location-specific expenditure studies. At the time of the study of GTM and Rookery Bay, the literature that best approximated spending across the reserves (due to the similarity in ecosystems, recreational and scientific opportunities, and partners) was from California. The differences in geography and type of site can create problems and unknown bias. The difference in consumer prices between the MBNMS in California and the reserve sites in Florida is another, smaller limitation. The MBNMS study sampled visitors who were close enough for day trips, so it likely underestimated lodging costs, among others.

Some of these limitations were addressed by using geographically similar regions and more appropriate populations with our last two sites. However, this study was limited by how it reported expenditures. While the MBNMS reported specific purchases, such as small restaurants, fuel, and boat charters, the National Survey of Fishing, Hunting, and Wildlife-Associated Recreation binned them into broad categories such as "lodging" and "equipment." Further, this survey measured activities throughout the state, while the MBNMS study was limited to a conserved area, similar to reserves.

A lack of visitation and use data contributed to the conservative estimates, as some visitor counts for certain activities had to be omitted. The South Slough Reserve is aware that hiking, boating, fishing, and hunting take place at the reserve but cannot accurately 
estimate participation levels. When reserves did estimate the visitors for activities, we asked them to be conservative to not overestimate the economic contribution.

\section{Discussion}

Economic contributions varied widely among reserves due to their size, location, and partners. GTM and Rookery Bay are both located near large urban centers and have many dependent partners. The large number of visitors and multiple partnerships generate larger contributions compared to the remote reserves. GTM and its partners see nearly a million annual visitors, while Rookery Bay and its partners host around 670,000 visitors annually. This resulted in contributions from all visitors (partner and reserve) that were nearly USD 44 million and just over USD 27 million for GTM and Rookery, respectively. While the total contributions from GTM and Rookery Bay were similar, the visitor contributions were substantially higher at the GTM Reserve and the partner contribution made up the difference, being over USD 15 million greater at the Rookery Bay Reserve compared to GTM. The Apalachicola Reserve is located in a more rural area and attracts an estimated half of a million visitors with its one partner each year. In contrast, South Slough sees far fewer visitors than the other reserves studied, just under 10,000 annually.

Each reserve's largest economic contribution relied on a different aspect of their operation. The bulk of South Slough's economic contributions came from their operational spending. Apalachicola's biggest economic contribution came through its visitors while GTM and Rookery Bay had substantial economic contributions through their partners' visitors and partners' spending, respectively; GTM's and Rookery Bay's biggest contributions were through their partners. Partners were only selected if they substantially or wholly relied on the reserve. These visitor-heavy reserves provide crucial habitat protection and maintenance for the operation of private companies. GTM has multiple organizations within its boundaries and Rookery Bay supports a large number of private ecotourism companies. The results highlight how federal and state investment in systems such as the NERRS can directly benefit local business. The support that local businesses receive creates an opportunity and incentive for local businesses to care about the quality of their local reserves. Apalachicola and South Slough had fewer partnerships, likely due to their remote locations compared to GTM and Rookery Bay. Having lower visitation does not lessen the overall value of more remote reserves. South Slough makes significant contributions to Coos County through its operational spending and Apalachicola still supports many annual visitors despite its remote location. The varying sources of contributions speaks to how each reserve operates differently based on its location.

Study region selection is an important component of an economic contribution or impact analysis, and there is a lack of literature that helps inform the inclusion of a geographic area based on a percent threshold of contribution. Including a larger area will increase the amount of spending and increases the direct outputs but can simultaneously reduce the contribution per area if including regions with smaller economic contributions. There is nothing technically incorrect about including a broader study area to capture all of the economic activity, but it can perhaps dilute the impact of the messaging for certain audiences within the geographic areas most responsible for the economic contribution or impact. Therefore, for our primary analyses, we focused on including geographies that covered the vast majority (probably ranging from about $80-95 \%$ ) of the economic activity (e.g., employees lived there, or a major vendor was located there) and where we could tell a meaningful qualitative story about why that region was included. The audience consideration is important as well as in some cases, there can be value in also generating outputs at a broader scale such as the state-level if the audience is a state-level decision maker. Our takeaway is that there are different advantages to more concentrated and broader study areas, and the audience receiving the data can be a major determinant of which one might be more impactful.

The contribution from each reserve's spending was much more consistent across reserves compared to other elements of this economic contribution analysis, ranging from 
just under USD 3 million at the Apalachicola Reserve to over USD 5.5 million at the GTM Reserve. This was not only affected by the reserves' budgets but also by large, non-annual spending projects. The funds brought in and spent outside of a reserve's typical budget, such as large dredging or construction projects that do not occur annually, can play a large role in the economic contribution to the region. This was especially true in South Slough, where the reserve brings in over USD 1 million a year through grants. The Apalachicola Reserve also had several restoration projects that brought in large funds.

Often, a large part of a reserve's economic contribution to the surrounding economy is tied to the region's visitation and tourism. This was the case for GTM, Rookery Bay, and Apalachicola, but it may not be true across the entire reserve system. While visitation is important, it is not the only contributor. Two reserves, Apalachicola and South Slough, are in rural areas. South Slough has fewer annual visitors than Apalachicola, but the various activities and numerous access points limit South Slough's ability to count visitors for activities that do not occur at the visitor center. Due to the vast area and numerous access points, we could not even make conservative estimates and had to leave out visitation from outdoor activities, such as hunting, fishing, and hiking. Apalachicola was able to use proxies in order to conservatively estimate the number of visitors for several activities.

A reserve's value is comprised of more than its economic contribution; therefore, it would be inappropriate to compare reserves based on this metric. Furthermore, the primary goal of establishing a NERR is to promote stewardship of coasts and estuaries, not to enhance economic development. These sites exist to further research, education, and conservation, and they are important parts of their communities. While many studies estimating the values of parks and similar natural areas focus solely on the contribution of ecotourism and visitor spending, our analysis demonstrates that reserves contribute to their surrounding communities and economies regardless of their tourism and visitor spending statistics $[15-17,20]$. For example, reserve and partner spending can be substantial contributors, regardless of a reserve's visitor statistics.

The focus on tourism dollars makes sense at the regional and national level. When studies are evaluating multiple sites, it would be resource and time intensive to collect budget information from all of the entities operating these areas. However, even studies that look at the individual park level $[13,15]$ neglect the operational spending of the umbrella agencies that are in charge of maintaining and governing the park or natural area and its visitors. Our results show that operations spending alone contributes around USD 3 to USD 5.5 million annually from each individual site. For studies that consider regional or national economic contributions that cover multiple sites, including operational and partner spending could significantly alter economic contribution results. This could be especially important for analysis of conservation areas that have less recreation focused goals, such as National Marine Sanctuaries.

IMPLAN proved to be a valuable tool to communicate results. While the Bureau of Economic Analysis' RIMS II multipliers provide a great mechanism to understand the aggregate economic contribution or impact in a region, IMPLAN can provide outputs by sector which can help gain support from those sectors that might benefit the most (e.g., those in hospitality). IMPLAN also provides versatility in providing outputs by multiple geographic areas (e.g., one could provide outputs for the primary county of the study, the primary county plus the adjacent county, and the entire state), which provides value when developing outputs for audiences and decision makers at different levels of government.

To enhance the defensibility and communication value of our analysis, we need to improve the accuracy of our estimates. The next step in improving our estimates is the development of reserve-specific expenditure and visitor profiles. Relatedly, better data on the split between study area residents and visitors from outside the area would increase the accuracy of the results as out-of-region visitors typically have larger spending profiles than residents. Identifying this difference between resident spending and out-of-region spending would also allow us to conduct economic impact analyses. This would identify 
the net change in economic activity as opposed to the existing value (as we did in this study) which would provide further value to the reserves.

\section{Using the Results at the Reserve Level}

Economic analyses have little impact if they are not effectively communicated to and used by decision makers [23]. The behavior of communities and the local policies they support influence the health of estuaries and ability of reserves to conserve and restore natural coastal habitats. There are many individuals and groups, such as reserve friends' groups and conservation commissions, that feel reserves are invaluable-but there may be others that do not feel connected to their local reserve or see its value. Part of NOAA's goals with this analysis was to explore ways in which economic benefits and contributions could be used by individual reserves to further their goals. Establishing connections between a reserve and economic benefits to the region may assist in increasing reserve support, and in turn support additional funding and policy.

The results from this analysis from one reserve were used to test messaging around economic information. Two stakeholder meetings were held with the reserve manager of the site and partners of the reserve (the local National Estuary Program and Sea Grant office) to discuss how they currently use economic data in their outreach and advocacy. This informed the content created for communicating the results of the analysis. We created 11 infographics with messages that connect economic values to key topics relevant to the region in conjunction with the reserve and partners: water quality, fisheries, climate adaptation, conservation, and jobs. These graphics contained short statements of the economic values from the economic contributions study and ecosystem service values, accompanied by a photograph or graphic image relating to the topic [24]. For example, one infographic would state how the reserve supports the local community's economy through providing jobs, supporting local fisheries, generating revenue, and savings in wastewater treatment costs. We then tested these messages through interviews with community members and additional reserve managers. These reviewers were provided with the infographics, a brief project description, and a short set of questions to think about regarding the clarity and usefulness of the messages. Other than the two reserve managers, the reviewers lived within the study area-some had ties and regularly used the reserve, while others did not. The following day, they took part in semi-structured interviews answering those questions and regarding any other reactions they had to the graphics and economic messages.

Overall, reviewers found the messages to clear and helpful. All of the reviewers commented on how the infographics gave a clearer idea of ways the reserve benefitted the community. The combined presentation of ecosystem service values along with economic contributions tells a more involved story than ecosystem services do alone. In fact, jobs may be the most important economic contribution of a reserve to some community members. Messages relating to local jobs and the reserve's contributions to water quality and fisheries were stated as the most impactful by all reviewers. Some reviewers mentioned their surprise at the reserve's contributions to water quality and jobs, as these were not topics they typically thought of in conjunction with the estuary. All but one of the reviewers commented that overall, the combination of messages highlights how the reserve supports other sectors. Most of the reviewers also stated that the messaging gave them a better understanding of the environmental advantages to the community provided by the reserve.

Further investigation is needed with a larger audience and more rigorous method to understand how economic information influences behavior change and long-term perceptions of a reserve. However, the test audience results indicate economic values could play a role in building support for reserves at a local level through showing how reserves are integral to many sectors within the region. Emphasizing economic contributions may prove useful in gaining support from those who may not be direct users of reserves or place a high value on the conservation or restoration of natural lands. 


\section{Conclusions}

Protected areas, such as reserves, have historically demonstrated their value through ecosystem service values. Economic contributions analyses can be used to complement ecosystem service values to show how the reserves support local jobs and businesses in the area. Economic contribution analyses support the case for investing in the reserves by showing how these areas benefit their local communities beyond their boundaries and direct users. Analyses can demonstrate how non-users of reserves still benefit from their existence in their community. Raising this awareness may bring additional support for funding the reserves or inspire communities to change their behavior to reduce harmful impacts on reserves if they know it will benefit them through bringing more patrons to their businesses.

Author Contributions: Conceptualization, P.W. and C.G.; methodology, O.S.-C. and H.S.; software, O.S.-C.; validation, P.W. and C.G.; formal analysis, O.S-C.; data curation, D.L.; writing-original draft preparation, H.S. and O.S.-C.; writing-review and editing, P.W. and C.G.; supervision, P.W. and C.G.; project administration, C.G. and D.L. All authors have read and agreed to the published version of the manuscript.

Funding: This research was funded by the NOAA Office for Coastal Management and The Pew Charitable Trusts.

Institutional Review Board Statement: Not applicable.

Informed Consent Statement: Not applicable.

Data Availability Statement: All subjects gave their informed consent for inclusion before they participated in the study. The data are not publicly available due to privacy concerns of the participants.

Conflicts of Interest: The funders had no role in the design of the study; in the collection, analyses, or interpretation of data; in the writing of the manuscript, or in the decision to publish the results.

\section{Appendix A}

Table A1. Total Annual Economic Contribution of GTM to Duval, Flagler, and St. Johns Counties.

\begin{tabular}{ccccc}
\hline Contribution & Employment & $\begin{array}{c}\text { Labor Income } \\
\text { (USD) }\end{array}$ & $\begin{array}{c}\text { Value Added } \\
\text { (USD) }\end{array}$ & $\begin{array}{c}\text { Output } \\
\text { (USD) }\end{array}$ \\
\hline Direct & 345.35 & $11,210,351.16$ & $17,902,453.81$ & $31,232,169.62$ \\
Indirect & 76.44 & $4,274,305.05$ & $7,134,942.52$ & $12,245,907.43$ \\
Induced & 99.42 & $4,640,825.48$ & $8,305,209.34$ & $14,149,314.45$ \\
Total & 521.21 & $20,125,481.69$ & $33,342,605.67$ & $57,627,391.50$ \\
\hline
\end{tabular}

Table A2. Contribution of GTM Spending to Duval, Flagler, and St. Johns Counties (Annual).

\begin{tabular}{ccccc}
\hline Contribution & Employment & Labor Income & Value Added & Output \\
\hline Direct & 25.45 & $784,644.29$ & $1,265,355.32$ & $2,250,708.57$ \\
Indirect & 3.76 & $216,758.63$ & $352,462.67$ & $605,248.06$ \\
Induced & 18.85 & $882,319.94$ & $1,583,127.38$ & $2,696,863.85$ \\
Total & 48.06 & $1,883,722.86$ & $3,200,945.37$ & $5,552,820.48$ \\
\hline
\end{tabular}

Table A3. Contribution of GTM Visitor Spending to Duval, Flagler, and St. Johns Counties (Annual).

\begin{tabular}{ccccc}
\hline Contribution & Employment & $\begin{array}{c}\text { Labor Income } \\
\text { (USD) }\end{array}$ & $\begin{array}{c}\text { Value Added } \\
\text { (USD) }\end{array}$ & $\begin{array}{c}\text { Output } \\
\text { (USD) }\end{array}$ \\
\hline Direct & 61.73 & $1,982,130.63$ & $3,355,075.90$ & $5,657,112.88$ \\
Indirect & 13.11 & $748,140.12$ & $1,206,809.34$ & $2,097,786.77$ \\
Induced & 15.19 & $708,446.95$ & $1,267,088.93$ & $2,158,705.96$ \\
Total & 90.03 & $3,438,717.70$ & $5,828,974.17$ & $9,913,605.61$ \\
\hline
\end{tabular}


Table A4. Contribution of Partner Spending to Duval, Flagler, and St. Johns Counties (Annual).

\begin{tabular}{ccccc}
\hline Contribution & Employment & $\begin{array}{c}\text { Labor Income } \\
\text { (USD) }\end{array}$ & $\begin{array}{c}\text { Value Added } \\
\text { (USD) }\end{array}$ & $\begin{array}{c}\text { Output } \\
\text { (USD) }\end{array}$ \\
\hline Direct & 47 & $1,663,188.54$ & $1,805,122.43$ & $3,972,738.33$ \\
Indirect & 14.72 & $750,200.59$ & $1,447,468.74$ & $2,366,853.33$ \\
Induced & 13.43 & $626,633.57$ & $1,120,589.41$ & $1,909,335.63$ \\
Total & 75.15 & $3,040,022.70$ & $4,373,180.58$ & $8,248,927.29$ \\
\hline
\end{tabular}

Table A5. Contribution of Partner Visitor Spending to Duval, Flagler, and St. Johns Counties (Annual).

\begin{tabular}{ccccc}
\hline Contribution & Employment & $\begin{array}{c}\text { Labor Income } \\
\text { (USD) }\end{array}$ & $\begin{array}{c}\text { Value Added } \\
\text { (USD) }\end{array}$ & $\begin{array}{c}\text { Output } \\
\text { (USD) }\end{array}$ \\
\hline Direct & 211.17 & $6,780,387.70$ & $11,476,900.16$ & $19,351,609.84$ \\
Indirect & 44.85 & $2,559,205.72$ & $4,128,201.78$ & $7,176,019.27$ \\
Induced & 51.95 & $2,423,425.02$ & $4,334,403.62$ & $7,384,409.02$ \\
Total & 307.97 & $11,763,018.44$ & $19,939,505.56$ & $33,912,038.13$ \\
\hline
\end{tabular}

GTM's support through visitation is shown in its top five affected sectors by revenue and employment. Hotels and restaurants, whose contribution is derived through visitation, make up three of the five sectors in both these tables. The other shared sector is IMPLAN code 493 (museums, historical sites, zoos, and parks), showing the extent to which, the reserve attracts visitors. Tables A6 and A7 show the five most affected sectors by employment and revenue for the GTM Reserve.

Table A6. Top Five Affected Sectors by Revenue.

\begin{tabular}{llcccc}
\hline & \multicolumn{1}{c}{ Sector } & $\begin{array}{c}\text { Direct } \\
\text { (USD) }\end{array}$ & $\begin{array}{c}\text { Indirect } \\
\text { (USD) }\end{array}$ & $\begin{array}{c}\text { Induced } \\
\text { (USD) }\end{array}$ & $\begin{array}{c}\text { Total } \\
\text { (USD) }\end{array}$ \\
\hline 1 & 499: hotels and motels, including casino hotels & $6,251,905$ & 14,670 & 8,527 & $6,275,103$ \\
2 & 502: limited-service restaurants & $4,856,040$ & 70,705 & 515,182 & $5,441,926$ \\
3 & 501: full-service restaurants & $4,856,040$ & 76,681 & 318,065 & $5,250,786$ \\
4 & 493: museums, historical sites, zoos, and parks & $3,972,738$ & 0 & 5,561 & $3,978,300$ \\
5 & 526: other local government enterprises & $3,519,154$ & 31,107 & 34,205 & $3,584,466$ \\
\hline
\end{tabular}

Table A7. Top Five Affected Sectors by Employment.

\begin{tabular}{clcccc}
\hline & \multicolumn{1}{c}{ Sector } & Direct & Indirect & Induced & Total \\
\hline 1 & 501: full-service restaurants & 93.7 & 1.5 & 6.1 & 101.3 \\
2 & 502: limited-service restaurants & 55.1 & 0.8 & 5.9 & 61.8 \\
3 & 499: hotels and motels, including casino hotels & 58.2 & 0.1 & 0.1 & 58.4 \\
4 & 493: museums, historical sites, zoos, and parks & 47.0 & 0.0 & 0.1 & 47.1 \\
5 & 400: retail—food and beverage stores & 16.8 & 0.1 & 3.2 & 20.0 \\
\hline
\end{tabular}

Table A8. Total Contribution of Rookery Bay to Lee and Collier Counties (Annual).

\begin{tabular}{ccccc}
\hline Contribution & Employment & $\begin{array}{c}\text { Labor Income } \\
\text { (USD) }\end{array}$ & $\begin{array}{c}\text { Value Added } \\
\text { (USD) }\end{array}$ & $\begin{array}{c}\text { Output } \\
\text { (USD) }\end{array}$ \\
\hline Direct & 344.8 & $11,421,312.31$ & $16,577,451.52$ & $31,249,658.53$ \\
Indirect & 90.77 & $4,290,416.62$ & $7,615,654.97$ & $13,188,427.95$ \\
Induced & 77.18 & $3,335,303.07$ & $6,231,980.28$ & $10,600,375.71$ \\
Total & 512.75 & $19,047,032.00$ & $30,425,086.77$ & $55,038,462.19$ \\
\hline
\end{tabular}


Table A9. Contribution of Rookery Bay Spending to Lee and Collier Counties (Annual).

\begin{tabular}{ccccc}
\hline Contribution & Employment & $\begin{array}{c}\text { Labor Income } \\
\text { (USD) }\end{array}$ & $\begin{array}{c}\text { Value Added } \\
\text { (USD) }\end{array}$ & $\begin{array}{c}\text { Output } \\
\text { (USD) }\end{array}$ \\
\hline Direct & 10.51 & $507,969.58$ & $1,041,217.18$ & $1,930,305.43$ \\
Indirect & 6.7 & $291,161.94$ & $406,187.47$ & $955,700.47$ \\
Induced & 11.52 & $495,625.59$ & $926,024.21$ & $1,577,182.76$ \\
Total & 28.73 & $1,294,757.11$ & $2,373,428.86$ & $4,463,188.66$ \\
\hline
\end{tabular}

Table A10. Contribution of Rookery Bay Visitation to Lee and Collier Counties (Annual).

\begin{tabular}{ccccc}
\hline Contribution & Employment & $\begin{array}{c}\text { Labor Income } \\
\text { (USD) }\end{array}$ & $\begin{array}{c}\text { Value Added } \\
\text { (USD) }\end{array}$ & $\begin{array}{c}\text { Output } \\
\text { (USD) }\end{array}$ \\
\hline Direct & 74.97 & $2,722,645.33$ & $4,501,492.86$ & $7,260,106.97$ \\
Indirect & 14.65 & $753,856.78$ & $1,240,857.37$ & $2,177,657.77$ \\
Induced & 15.19 & $657,036.19$ & $1,228,206.14$ & $2,087,352.95$ \\
Total & 104.81 & $4,133,538.30$ & $6,970,556.37$ & $11,525,117.69$ \\
\hline
\end{tabular}

Table A11. Contribution of Partner Employment to Lee and Collier Counties (Annual).

\begin{tabular}{ccccc}
\hline Contribution & Employment & $\begin{array}{c}\text { Labor Income } \\
\text { (USD) }\end{array}$ & $\begin{array}{c}\text { Value Added } \\
\text { (USD) }\end{array}$ & $\begin{array}{c}\text { Output } \\
\text { (USD) }\end{array}$ \\
\hline Direct & 159 & $4,547,785.76$ & $5,011,723.88$ & $12,345,190.48$ \\
Indirect & 49.82 & $2,236,734.15$ & $4,308,337.40$ & $7,141,353.87$ \\
Induced & 30.14 & $1,303,523.94$ & $2,434,404.62$ & $4,142,952.40$ \\
Total & 238.96 & $8,088,043.85$ & $11,754,465.90$ & $23,629,496.75$ \\
\hline
\end{tabular}

Table A12. Contribution of Partner Visitation to Lee and Collier Counties (Annual).

\begin{tabular}{ccccc}
\hline Contribution & Employment & $\begin{array}{c}\text { Labor Income } \\
\text { (USD) }\end{array}$ & $\begin{array}{c}\text { Value Added } \\
\text { (USD) }\end{array}$ & $\begin{array}{c}\text { Output } \\
\text { (USD) }\end{array}$ \\
\hline Direct & 101.09 & $3,669,986.22$ & $6,068,096.84$ & $9,787,340.30$ \\
Indirect & 19.75 & $1,016,117.26$ & $1,672,405.24$ & $2,934,959.62$ \\
Induced & 20.48 & $885,627.47$ & $1,655,514.63$ & $2,813,569.81$ \\
Total & 141.32 & $5,571,730.95$ & $9,396,016.71$ & $15,535,869.73$ \\
\hline
\end{tabular}

Rookery Bay's support through visitation is shown in its top five affected sectors by revenue and employment. Hotels and restaurants, whose contribution is derived through visitation, make up three of the five sectors in both of these tables. The top affected sector for both employment and revenue was 493 (museums, historical sites, zoos, and parks), showing the extent to which the reserve attracts visitors. Tables A13 and A14 show the five most affected sectors by employment and revenue for the Rookery Bay Reserve.

Table A13. Top Five Affected Sectors by Employment.

\begin{tabular}{llcccc}
\hline & \multicolumn{1}{c}{ Sector } & Direct & Indirect & Induced & Total \\
\hline 1 & 493: museums, historical sites, zoos, and parks & 159.0 & 0.0 & 0.1 & 159.1 \\
2 & 501: full-service restaurants & 59.9 & 1.9 & 5.6 & 67.3 \\
3 & 502: limited-service restaurants & 34.3 & 0.5 & 3.8 & 38.6 \\
4 & 499: hotels and motels, including casino hotels & 35.3 & 0.3 & 0.1 & 35.7 \\
5 & 440: real estate & 0.0 & 26.4 & 6.9 & 33.3 \\
\hline
\end{tabular}


Table A14. Top Five Affected Sectors by Revenue.

\begin{tabular}{|c|c|c|c|c|c|}
\hline & Sector & $\begin{array}{l}\text { Direct } \\
\text { (USD) }\end{array}$ & $\begin{array}{c}\text { Indirect } \\
\text { (USD) }\end{array}$ & $\begin{array}{l}\text { Induced } \\
\text { (USD) }\end{array}$ & $\begin{array}{c}\text { Total } \\
\text { (USD) }\end{array}$ \\
\hline 1 & 493: museums, historical sites, zoos, and parks & $12,345,190$ & 0 & 4350 & $12,349,541$ \\
\hline 2 & 440: real estate & 0 & $3,899,342$ & $1,027,199$ & $4,926,541$ \\
\hline 3 & 499: hotels and motels, including casino hotels & $4,243,354$ & 30,887 & 9567 & $4,283,808$ \\
\hline 4 & 502: limited-service restaurants & $3,295,938$ & 47,932 & 367,339 & $3,711,210$ \\
\hline 5 & 501: full-service restaurants & $3,295,938$ & 104,385 & 306,139 & $3,706,463$ \\
\hline
\end{tabular}

Table A15. Total Contribution of South Slough to Coos County (Annual).

\begin{tabular}{ccccc}
\hline Contribution & Employment & $\begin{array}{c}\text { Labor Income } \\
\text { (USD) }\end{array}$ & $\begin{array}{c}\text { Value Added } \\
\text { (USD) }\end{array}$ & $\begin{array}{c}\text { Output } \\
\text { (USD) }\end{array}$ \\
\hline Direct & 49.39 & $1,633,058.61$ & $1,949,135.63$ & $3,787,285.15$ \\
Indirect & 9.29 & $368,753.34$ & $618,997.55$ & $1,428,093.51$ \\
Induced & 7 & $288,685.08$ & $537,674.59$ & $937,276.26$ \\
Total & 65.68 & $2,290,497.03$ & $3,105,807.77$ & $6,152,654.92$ \\
\hline
\end{tabular}

Table A16. Contribution of South Slough Spending to Coos County (Annual).

\begin{tabular}{ccccc}
\hline Contribution & Employment & $\begin{array}{c}\text { Labor Income } \\
\text { (USD) }\end{array}$ & $\begin{array}{c}\text { Value Added } \\
\text { (USD) }\end{array}$ & $\begin{array}{c}\text { Output } \\
\text { (USD) }\end{array}$ \\
\hline Direct & 41.82 & $1,378,907.98$ & $1,616,651.07$ & $3,226,006.78$ \\
Indirect & 8.3 & $326,692.11$ & $552,647.04$ & $1,282,598.44$ \\
Induced & 5.95 & $245,384.34$ & $456,968.76$ & $796,622.94$ \\
Total & 56.07 & $1,950,984.43$ & $2,626,266.87$ & $5,305,228.16$ \\
\hline
\end{tabular}

Table A17. Contribution of South Slough Visitation to Coos County (Annual).

\begin{tabular}{ccccc}
\hline Contribution & Employment & $\begin{array}{c}\text { Labor Income } \\
\text { (USD) }\end{array}$ & $\begin{array}{c}\text { Value Added } \\
\text { (USD) }\end{array}$ & $\begin{array}{c}\text { Output } \\
\text { (USD) }\end{array}$ \\
\hline Direct & 7.57 & $254,150.63$ & $332,484.56$ & $561,278.36$ \\
Indirect & 0.99 & $42,061.24$ & $66,350.51$ & $145,495.07$ \\
Induced & 1.05 & $43,300.74$ & $80,705.82$ & $140,653.32$ \\
Total & 9.61 & $339,512.61$ & $479,540.89$ & $847,426.75$ \\
\hline
\end{tabular}

Tables A18 and A19 show the top sectors affected by the contribution from the South Slough Reserve. Note that these include construction and local government, which were not in the top sectors affected by other reserves.

Table A18. Top Five Affected Sectors by Employment.

\begin{tabular}{llcccc}
\hline \multicolumn{1}{c}{ Sector } & Direct & Indirect & Induced & Total \\
\hline 1 & 501: museums, historical sites, zoos, and parks & 40.0 & 0.0 & 0.0 & 40.0 \\
2 & 447: other real estate & 0.0 & 3.0 & 0.2 & 3.2 \\
3 & 56: construction of other new nonresidential structures & 1.5 & 0.0 & 0.0 & 1.5 \\
4 & 410: retail—sporting goods, hobby, musical instrument & 1.3 & 0.0 & 0.1 & 1.4 \\
5 & and bookstores & 0.6 & 0.3 & 0.4 & 1.3 \\
\hline
\end{tabular}


Table A19. Top Five Affected Sectors by Revenue.

\begin{tabular}{|c|c|c|c|c|c|}
\hline & Sector & $\begin{array}{l}\text { Direct } \\
\text { (USD) }\end{array}$ & $\begin{array}{l}\text { Indirect } \\
\text { (USD) }\end{array}$ & $\begin{array}{c}\text { Induced } \\
\text { (USD) }\end{array}$ & $\begin{array}{c}\text { Total } \\
\text { (USD) }\end{array}$ \\
\hline 1 & 501: museums, historical sites, zoos, and parks & $3,057,745$ & 0 & 1028 & $3,058,773$ \\
\hline 2 & 447: other real estate & 0 & 510,826 & 36,676 & 547,503 \\
\hline 3 & 534: other local government enterprises & 0 & 160,779 & 43,737 & 204,516 \\
\hline 4 & 449: owner-occupied dwellings & 0 & 0 & 184,025 & 184,025 \\
\hline 5 & 56: construction of other new nonresidential structures & 121,837 & 0 & 0 & 121,837 \\
\hline
\end{tabular}

Table A20. Total Contribution of Apalachicola to Franklin County (Annual).

\begin{tabular}{ccccc}
\hline Contribution & Employment & $\begin{array}{c}\text { Labor Income } \\
\text { (USD) }\end{array}$ & $\begin{array}{c}\text { Value Added } \\
\text { (USD) }\end{array}$ & $\begin{array}{c}\text { Revenue } \\
\text { (USD) }\end{array}$ \\
\hline Direct & 554.94 & $11,920,647.30$ & $16,730,455.36$ & $31,620,557.98$ \\
Indirect & 68.95 & $1,975,490.09$ & $3,593,004.55$ & $9,277,626.79$ \\
Induced & 40.44 & $1,206,506.11$ & $3,050,622.00$ & $5,510,303.29$ \\
Total & 664.33 & $15,102,643.50$ & $23,374,081.91$ & $46,408,488.06$ \\
\hline
\end{tabular}

Table A21. Contribution of Apalachicola Spending to Franklin County (Annual).

\begin{tabular}{ccccc}
\hline Contribution & Employment & $\begin{array}{c}\text { Labor Income } \\
\text { (USD) }\end{array}$ & $\begin{array}{c}\text { Value Added } \\
\text { (USD) }\end{array}$ & $\begin{array}{c}\text { Revenue } \\
\text { (USD) }\end{array}$ \\
\hline Direct & 20.67 & $734,409.28$ & $955,937.81$ & $1,886,313.87$ \\
Indirect & 4.81 & $134,959.37$ & $271,282.66$ & $698,244.82$ \\
Induced & 2.47 & $73,805.00$ & $186,715.98$ & $337,105.15$ \\
Total & 27.95 & $943,173.65$ & $1,413,936.45$ & $2,921,663.84$ \\
\hline
\end{tabular}

Table A22. Contribution of Apalachicola Visitation to Franklin County (Annual).

\begin{tabular}{ccccc}
\hline Contribution & Employment & $\begin{array}{c}\text { Labor Income } \\
\text { (USD) }\end{array}$ & $\begin{array}{c}\text { Value Added } \\
\text { (USD) }\end{array}$ & $\begin{array}{c}\text { Revenue } \\
\text { (USD) }\end{array}$ \\
\hline Direct & 516.16 & $10,800,035.24$ & $15,230,976.21$ & $28,705,557.45$ \\
Indirect & 61.85 & $1,774,888.04$ & $3,202,857.38$ & $8,271,735.60$ \\
Induced & 36.66 & $1,093,455.41$ & $2,764,675.02$ & $4,993,957.08$ \\
Total & 614.67 & $13,668,378.69$ & $21,198,508.61$ & $41,971,250.13$ \\
\hline
\end{tabular}

Table A23. Contribution of Partner Employment to Franklin County (Annual).

\begin{tabular}{ccccc}
\hline Contribution & Employment & $\begin{array}{c}\text { Labor Income } \\
\text { (USD) }\end{array}$ & $\begin{array}{c}\text { Value Added } \\
\text { (USD) }\end{array}$ & $\begin{array}{c}\text { Revenue } \\
\text { (USD) }\end{array}$ \\
\hline Direct & 1 & $35,248.55$ & $43,957.21$ & $81,898.47$ \\
Indirect & 0.24 & $6,533.00$ & $13,186.16$ & $34,851.54$ \\
Induced & 0.12 & $3,488.26$ & $8,828.36$ & $15,933.59$ \\
Total & 1.36 & $45,269.81$ & $65,971.73$ & $132,683.60$ \\
\hline
\end{tabular}

Table A24. Contribution of Partner Visitation to Franklin County (Annual).

\begin{tabular}{ccccc}
\hline Contribution & Employment & $\begin{array}{c}\text { Labor Income } \\
\text { (USD) }\end{array}$ & $\begin{array}{c}\text { Value Added } \\
\text { (USD) }\end{array}$ & $\begin{array}{c}\text { Revenue } \\
\text { (USD) }\end{array}$ \\
\hline Direct & 17.11 & $350,954.22$ & $499,584.14$ & $946,788.19$ \\
Indirect & 2.04 & $59,109.68$ & $105,678.35$ & $272,794.83$ \\
Induced & 1.2 & $35,757.43$ & $90,402.64$ & $163,307.47$ \\
Total & 20.35 & $445,821.33$ & $695,665.13$ & $1,382,890.49$ \\
\hline
\end{tabular}

Tables A25 and A26 contain the top sectors affected by the contribution from the Apalachicola Reserve. Accommodations and service are highly affected compared to other 
sectors, especially due to the large volume of visitors, as shown in Table A22. The highestrevenue sectors are those involving service and tourism, such as sightseeing and amusement.

Table A25. Top Five Affected Sectors by Employment.

\begin{tabular}{|c|c|c|c|c|c|}
\hline & Sector & Direct & Indirect & Induced & Total \\
\hline 1 & 418: transit and ground passenger transportation & 173.3 & 0.9 & 1.0 & 175.2 \\
\hline 2 & 504: other amusement and recreation industries & 95.1 & 0.1 & 0.4 & 95.6 \\
\hline 3 & 508: other accommodations & 66.2 & 0.0 & 0.0 & 66.2 \\
\hline 4 & 511: all other food and drinking places & 39.2 & 5.6 & 1.8 & 46.6 \\
\hline 5 & 507: hotels and motels, including casino hotels & 39.8 & 0.0 & 0.0 & 39.8 \\
\hline
\end{tabular}

Table A26. Top Five Affected Sectors by Revenue.

\begin{tabular}{|c|c|c|c|c|c|}
\hline & Sector & $\begin{array}{l}\text { Direct } \\
\text { (USD) }\end{array}$ & $\begin{array}{c}\text { Indirect } \\
\text { (USD) }\end{array}$ & $\begin{array}{c}\text { Induced } \\
\text { (USD) }\end{array}$ & $\begin{array}{l}\text { Total } \\
\text { (USD) }\end{array}$ \\
\hline 1 & 504: other amusement and recreation industries & $4,824,765$ & 6495 & 20,099 & $4,851,360$ \\
\hline 2 & 508: other accommodations & $3,915,363$ & 0 & 3 & $3,915,367$ \\
\hline 3 & 507: hotels and motels, including casino hotels & $3,915,063$ & 5 & 10 & $3,915,079$ \\
\hline 4 & $\begin{array}{l}\text { 420: scenic and sightseeing transportation and support } \\
\text { activities for transportation }\end{array}$ & $3,155,863$ & 700,233 & 26,446 & $3,882,541$ \\
\hline 5 & 418: transit and ground passenger transportation & $3,166,113$ & 17,074 & 17,847 & $3,201,035$ \\
\hline
\end{tabular}

\section{References}

1. Yee, S.H.; Sullivan, A.; Williams, K.C.; Kirsten, W. Who Benefits from National Estuaries? Applying the FEGS Classification System to Identify Ecosystem Services and their Beneficiaries. Int. J. Environ. Res. Public Health 2019, 16, 2351. [CrossRef] [PubMed]

2. National Oceanic and Atmospheric Association, National Estuarine Research Reserve System. Available online: https://coast. noaa.gov/nerrs/about/ (accessed on 10 February 2021).

3. Angulo-Valdes, J.A.; Hatcher, B.G. A new typology of benefits derived from marine protected areas. Mar. Policy 2017, 34, 635-644. [CrossRef]

4. Torres, C.; Hanley, N. Communicating research on the economic valuation of coastal and marine ecosystem services. Mar. Policy 2017, 75, 99-107.

5. Watson, J.E.; Dudley, N.; Segan, D.B.; Hockings, M. The performance and potential of protected areas. Nature 2014, 515, 67-73. [CrossRef] [PubMed]

6. Haefele, M.; Loomis, J.; Bilmes, L.J. Total Economic Valuation of the National Park Service Lands and Programs: Results of a Survey of the American Public; Harvard Environmental Economics Program: Cambridge, MA, USA, 2016.

7. Himes-Cornell, A.; Pendleton, L.; Atiyah, P. Valuing ecosystem services from blue forests: A systematic review of the valuation of salt marshes, sea grass beds and mangrove forests. Ecosyst. Serv. 2018, 30, 36-48. [CrossRef]

8. Joshi, O.; Henderson, J.E.; Tanger, S.M.; Boby, L.A.; Pelkki, M.H.; Taylor, E.L. A synopsis of methodological variations in economic contribution analyses for forestry and forest-related industries in the US South. J. For. 2017, 115, 80-85. [CrossRef]

9. Rahe, M.; van Dis, K.; Gwin, L. Communicating economic impact assessments: How research results influence decision-maker attitudes toward the local food sector. J. Agric. Food Syst. Community Dev. 2019, 8, 95-105.

10. Leeworthy, V.R.; Schwarzmann, D.; Saade, D.R. A Socioeconomic Profile of Recreation Users of the California Northern Central Coast Region, Greater Farallones National Marine Sanctuary and the Northern Portion of Monterey Bay National Marine Sanctuary, 2011; U.S. Department of Commerce; National Oceanic and Atmospheric Association; Office of National Marine Sanctuaries: Silver Springs, MD, USA, 2015.

11. Flores, L.; Schwartz, A. Economic Contribution of Outdoor Recreationto Whatcom County, Washington; Earth Economics: Tacoma, WA, USA, 2014.

12. McGrath, J.; Primm, D.; Lafe, W. Heritage tourism's economic contribution: A Pennysylvania case study. Tour. Econ. 2016, 23, 1131-1137. [CrossRef]

13. Mowen, A.J.; Graefe, A.R.; Trauntvein, N.E.; Stynes, D.J. The Economic Significance and Impact of Pennsylvania State Parks: An Updated Assessment of 2010 Park Visitor Spending on the State and Local Economy; Pennsylvania Department of Conservation and Natural Resources: Harrisburg, PA, USA, 2012.

14. Munn, I.; Hussain, A.; Spurlock, S.; Henderson, J. Economic Impact of Fishing, Hunting, and Wildlife-Associated Recreation Expenditures on the Southeast U.S. Regional Economy: An Input-Output Analysis. Hum. Dimens. Wildl. 2010, 15, 433-449. [CrossRef] 
15. Saayman, M.; Saayman, A. Estimating the Economic Contribution of Visitor Spending in the Kruger National Park to the Regional Economy. J. Sustain. Tour. 2006, 14, 67-81. [CrossRef]

16. Steinback, S.R. Regional economic impact assessments of recreational fisheries: An application of the IMPLAN modeling system to marine party and charter boat fishing in Maine. N. Am. J. Fish. Manag. 1999, 19, 724-736. [CrossRef]

17. Thilmany, D.; Sullins, M.; Ansteth, A. The 2006 Economic Contribution of Agritourism to Colorado: Estimates from a Survey of Colorado Tourists. Ph.D. Thesis, Colorado State University, Fort Collins, CO, USA, 2007.

18. Watson, P.; Wilson, J. Thilmany and S. Winter, Determining Economic Contributions and Impacts: What is the difference and why do we care? J. Reg. Anal. Policy 2007, 37, 140-147.

19. Willis, D.B.; Straka, T.J. The Economic Contribution of Natural Resources to a State Economy: A South Carolina Case Study. Nat. Resour. 2017, 8, 115-129. [CrossRef]

20. Hjerpe, E.; Holmes, T.; White, E. National and community market contributions of Wilderness. Soc. Nat. Resour. 2017, 30, 265-280. [CrossRef]

21. Church, J.D. Comparing the Consumer Price Index with the gross domestic product implicit price deflator. Mon. Labor Rev. 2016, $139,1$.

22. U.S. Department of the Interior; U.S. Fish and Wildlife Service; U.S. Department of Commerce; U.S. Census Bureau. 2011 National Survey of Fishing, Hunting, and Wildlife-Associated Recreation; U.S. Department of the Interior; U.S. Fish and Wildlife Service; U.S. Department of Commerce; U.S. Census Bureau: Washington, DC, USA, 2011.

23. Drucker, J. Economic Impact Analysis amid Rapid Change: Challenges, Strategies, and Examples from Defense Communities. J. Plan. Educ. Res. 2015, 35, 401-418. [CrossRef]

24. NOAA Office of Coastal Management. New Hampshire Department of Environmental Services Coastal Program, Eastern Research Group, Inc, How People Benefit from New Hampshire's Great Bay Estuary; National Oceanic and Atmospheric Administration: Silver Springs, MD, USA, 2016. 